\title{
Antifungal Activity of Cymbopogon citratus Essential Oil on Toxigenic Fungal Strains Isolated from Cameroonian Rice
}

\author{
N. D. Nganou ${ }^{1 *}$, E. S. Tchinda ${ }^{1}$, A. T. Sokamte ${ }^{2}$, M.T.N. Beumo ${ }^{2}$, \\ S. F. Nodem ${ }^{2}$ and L. N. Tatsadjieu ${ }^{1}$
}

${ }^{1}$ Bioprecess Laboratory, Department of Food Technology and Quality Control, University Institute of Technology, University of Ngaoundéré, P.O. Box 455, Ngaoundéré, Cameroon.

${ }^{2}$ Food Microbiology and Biotechnology Laboratory, Department of Food Science and Nutrition, National Advanced School of Agro-Industrial Sciences, University of Ngaoundéré, P.O. Box 455, Ngaoundéré, Cameroon

*Corresponding author

\section{A B S T R A C T}

With a view to finding alternative compounds to the synthetic chemicals used in food preservation, a study was initiated to evaluate the antifungal activity of $C$. citratus essential oil on toxigenic molds isolated from Cameroonian rice. To this end, 12 rice samples of one kilogram each was taken in October 2019 in four cities

\section{Keywords}

Rice, Mycotoxins, Toxigenic molds, Cymbopogon citratus

\section{Article Info}

Accepted:

10 July 2020

Available Online:

10 August 2020 in Cameroon: Tonga, Ndop, Yagua and Maga. Water activity in the rice samples collected was measured using an electronic hygrometer; mycotoxins were determined by HPLC. The isolation and identification of fungal strains were done on the basis of macroscopic and microscopic characteristics, and the identity of the strains was confirmed by PCR-sequencing. The extraction of the essential oil was done using a Clevenger by hydrodistillation, and the analysis of its chemical composition by GC/MS. From these analyses, it appears that all samples tested are contaminated with at least one mycotoxin, and that the three mycotoxins tested (AFB1, CIT and OTA) are indeed present in our rice samples, but at values not exceeding the limits set by European Commission Regulation N0 1881/2006. Seven cases of co-contamination have been identified. On the other hand, 9 fungal genera have been identified and the dominant genera being Aspergillus, Penicillium and Fusarium, all of which are involved in the synthesis and excretion of mycotoxins in cereals. The essential oil of $C$. citratus has been shown to be effective in inhibiting the growth of $A$. carbonarius, A. versicolor, $F$. graminaerum, $F$. moniliform and $P$. citrinum; and the main compounds of this oil are geranial (42.4\%), neral (33.5\%) and myrcene (10.8). A. carbonarius was the most sensitive strain to the essential oil, and $F$. moniliform was the most resistant strain. 


\section{Introduction}

Rice (Oryza sativa L.) is the staple food of more than half of the world's population. It plays a central role in the food security of the poorest categories of rural and urban populations because of the ease and low cost of its preparation, low prices and the regularity of supply, which is covered in Cameroon by imports (Folefack and Abou, 2016). The development of the rice sector can become an engine of economic growth for the African continent and thus contribute to eradicating extreme poverty and food insecurity, as well as to improving the wellbeing of populations (FAO, 2011).Indeed, in Cameroon, according to the INS (National Institute of Statistics) the production of paddy rice (unshelled rice) has increased by $12 \%$ to reach 311.674 tons in 2016, and the two major agro-ecological zones covering $94 \%$ of local production are the North and the West (FAO, 2011). However, demand is still outstripping supply, which increases the rate of rice imports. This low yield is said to be due to the many problems encountered in rice cultivation, including physical constraints linked to climatic factors (temperature, solar radiation); edaphic constraints, i.e. those linked to the nature of the soil; constraints linked to the choice of varieties and during harvesting; and finally biological constraints such as the attack of rice by pests, termites, weeds and molds (Moreau, 1974; Laib, 2011). In addition, it has been reported that mold growth on cereals during the storage period can cause about $50-80 \%$ of losses under storage conditions favorable to their development (Kossou and Aho, 1993). Indeed, mold contamination of rice is a huge problem nowadays, because many molds (of the genera Fusarium, Penicillium, and Aspergillus) are known to naturally produce mycotoxins, which represent a potential hazard if consumed by humans or animals (Alshannaq and $\mathrm{Yu}, 2017$ ). The most dangerous and regularly monitored mycotoxins are afloxins and ochratoxins (Nganou et al., 2014).These mycotoxins can cause diseases for both rice and consumers (Bennett and Klich, 2003). To deal with this problem caused by mold, many control methods have been developed, including the use of synthetic chemicals. This technique has proven to be effective and has convincing results, but has devastating repercussions on the environment and human health through acute or chronic intoxication, allergies and even cancers (Wopereis et al., 2009). In the face of increasing mistrust of synthetic chemicals, the use of natural products, particularly plant extracts (essential oils), is a wise alternative to protect crops, the environment and living organisms (Amadioha, 2000; Iftikhar et al., 2010; Tchinda, 2018). Essential oils are indeed volatile substances extracted from aromatic plants which are of increasing interest in the food and pharmaceutical industries (Ngono et al., 2000). These plant substances exhibit biodegradability, low persistence, and specific toxicity to a number of microorganisms (Park et al., 2002; Regnault-Roger et al., 2008). These natural pesticides have already been the subject of several studies, notably the case of the essential oil of $O$. gratissimum which has shown its efficacy against two fungal strains (B. oryzea and A. padwickii) responsible for post-harvest losses in rice in Cameroon (Bengyella et al., 2011). In addition, Siewe et al., (2015) showed that essential oils of S. aromaticum and $C$. citratus could be used effectively to control $E$. coli and $S$. aureus during the preservation of beef pâté. It is in the same perspective that the present work was initiated and aims to highlight the toxigenic fungal profile of Cameroonian rice and the antifungal activity of the essential oil of $C$. citratus on the inhibition of the growth of isolated strains, because at the limit of our knowledge, no study has yet been conducted in this direction. 


\section{Materials and Methods}

\section{Sampling}

The rice samples used in this study were taken in October 2019 in four cities in Cameroon: Tonga, Ndop, Yagoua and Maga. These cities were chosen because they produce most of the rice made in Cameroon that is sold in Cameroonian markets. Twelve rice samples from these four sites were collected, with 3 samples per site. One kilogram of each sample once purchased was immediately packaged, labeled and stored in sterile, leak-proof plastic packaging and transported to the laboratory for analysis. Fifteen kilograms of lemongrass (C. citratus) leaves were harvested on 10 September 2019 in the city of Ngaoundéré/Cameroon. They are the ones that have undergone an extraction to obtain the essential oil used for antifungal tests.

\section{Determination of the water content of rice}

The water content of the rice samples was determined according to the following procedure: $5 \mathrm{~g}$ of rice was placed in cups, weighed and dried in the oven at $105^{\circ} \mathrm{C}$ for about 24 hours. Then, the unit was removed, cooled in a desiccator and weighed a second time. The water content was calculated as follows:

Water content $(\%)={ }^{\frac{\text { M1-M2 }}{\text { M1-M0 }}}$ X100 with:

M1: weight of the cup and rice before drying M2: weight of the cup and rice after drying M0: weight of the cup without rice

\section{Water activity}

Water activity, which is defined as the amount of water available in a food, was measured using an electronic hygrometer. To do this, $3 \mathrm{~g}$ of rice was taken, then placed in a cup, and inserted into the hygrometer for reading. This hygrometer is coupled to a computer which receives the information transmitted by the latter.

\section{Isolation, purification and identification of fungal flora}

\section{Isolation}

The method described by Pitt and Hocking (2009) was used. After cleaning the surface of the rice grains in a $1 \%$ aqueous solution of $\mathrm{NaOCl}$, they were rinsed three times with sterile distilled water for a total of 15 minutes. Ten grains thus cleaned were placed in Petri dishes containing DG18 culture medium, supplemented with chloramphenicol $(60 \mu \mathrm{g} / \mathrm{mL})$. Incubation was carried out at $25 \pm$ $2{ }^{\circ} \mathrm{C}$ for 5 to 7 days, and visual observations were made every 24 hours. The resulting fungal colonies were removed using the sterile platinum loop and were purified. After 7 days of incubation, the fungal contamination parameters of the rice grains were calculated.

The contamination rate of rice grains was calculated as follows:

$$
\% \mathrm{GC}=\frac{\mathrm{NCG}}{\mathrm{NSW}} \times 100
$$

Where,

GC: Percentage of contaminated grain

NCG: Number of contaminated grains at the end of the incubation period.

NSW: Total number of grains sown

The fungal frequency (FF) of each species was calculated using the following formula:

$\% \mathrm{FF}=$ number of isolates of a fungal species detected in a sample/total number of fungal isolates detected in a sample. 


\section{Identification}

The isolated strains were purified using the successive dilution method described by Bavaro et al., (2017). The identification of isolated mold strains was carried out on the basis of morphological characteristics. The morphological identification keys described by Samson et al., (2004) and the laboratory guide for the identification of different mold species (Booth, 1977) were used as a reference for mold identification.

\section{DNA extraction from molds, PCR} amplification and sequencing

Purified fungal colonies were removed from the Petri dishes under aseptic conditions, using sterile distilled water with $0.1 \%$ Tween 80. Then the extraction of DNA from the molds was done according to the protocol described by El Sheikha and Nganou (2018).

DNA was quantified spectrophotometrically with a NanoDrop ND-1000 (NanoDrop Technologies, Wilmington, USA) and kept at $20^{\circ} \mathrm{C}$ until used as a template for PCR amplification. In addition, the successful application of a universal eukaryotic primer for PCR permitted the amplification and identification of many fungi species in a unique PCR step.

Universal eukaryotic primer for PCR was successfully applied to amplify and identify several species of fungi in a unique PCR step. In previous reported studies, a fragment of a specific region of the $28 \mathrm{~S}$ rDNA called the D2 region, was amplified while using the following universal eukaryotic primers: forward, U1f GC (5' - CGC CCG CCG CGC GCG GCG GGC GGG GCG GGG GTG AAA TTG TTG AAA GGG AA - 3') and reverse, U2r (5' - GAC TCC TTG GTC CGT GTT - 3') [24-27]. In the present study, after the addition a 30 bp GC clamp (Sigma) on the forward universal eukaryotic primer procured from Sigma, PCR was carried out in a final volume of $50 \mu \mathrm{L}$ containing: $1.5 \mathrm{mM}$ of $\mathrm{MgCl}_{2}, 5 \mu \mathrm{L}$ of $\mathrm{MgCl}_{2}$-free $10 x \mathrm{Taq}$ reaction buffer (Promega), all the deoxyribonucleotide triphosphate (dNTPs) at $200 \mu \mathrm{M}, 0.2 \mu \mathrm{M}$ of each primer, $2 \mu \mathrm{L}$ of extracted DNA $(\approx 30 \mathrm{ng})$ and 1.25 Units of Taq DNA polymerase (Promega). The amplification conditions were an initial denaturation for $3 \mathrm{~min}$ at $94^{\circ} \mathrm{C}, 30$ cycles of heating at $94^{\circ} \mathrm{C}$ for $45 \mathrm{sec}$, cooling at $50^{\circ} \mathrm{C}$ for $50 \mathrm{sec}$, heating at $72^{\circ} \mathrm{C}$ for $90 \mathrm{sec}$ and a final extension of $5 \mathrm{~min}$ at $72^{\circ} \mathrm{C}$.

PCR products were verified by electrophoresis by loading $5 \mu \mathrm{L}$ on $2 \%$ TAE agarose gels with $100 \mathrm{pb}$ molecular weight ladder. Gels were stained and photographed as mentioned above. PCR products were purified of DNA from low melting agarose gel, with the Wizard PCR temperature Preps DNA purification system. Then were reamplified under the same conditions but in this case using primers without GC-clamp and then sent for sequencing at GATC Biotech (Germany). The sequences of the 28S rDNA obtained were compared with those of the database available at NCBI GenBank (National Center for Biotechnology Information databases) using the BLAST program to determine the closest known sequences.

\section{Determination of mycotoxins in different samples of rice}

The mycotoxins that have been quantified are ochratoxin A (OTA), aflatoxin B1 (AFB1) and citrine (CIT). The dry rice samples were frozen at $-80^{\circ} \mathrm{C}$, then $20 \mathrm{~g}$ of this sample was placed in a "mixer blender" (Perten Laboratory Mill 3600) containing $100 \mathrm{~mL}$ of the extraction solvent (methanol $+3 \%$ bicarbonate solution, 50+50). The mixture was homogenized for $2 \mathrm{~min}$ at maximum speed. The resulting mixture was centrifuged 
in a refrigerated centrifuge at $3000 \mathrm{rpm}$ for 30 min, and $25 \mathrm{~mL}$ of the supernatant was recovered. Subsequently, in $30 \mathrm{~mL}$ of PH 7.3 phosphate buffer (PBS), $10 \mathrm{~mL}$ of the extract was diluted, and the sample was placed in an immunoaffinity column (Ochraprep®, Rhône Diagnostics, Scotland). In the end, the toxin was released by elution from the column with methanol, as it allows the destruction of the antigen/antibody bonds by modifying the structure of the antibodies. The methanol was evaporated under a nitrogen stream at $70^{\circ} \mathrm{C}$, and the residue was taken up by $1 \mathrm{~mL}$ of the mobile phase (water/acetonitrile/acetic acid, 51: 48: $1, \mathrm{v} / \mathrm{v} / \mathrm{v}$ ) in a vial for HPLC analysis. Optimal detection conditions for each toxin are obtained by applying the following excitation and fluorescence emission parameters: 365 and $440 \mathrm{~nm}$ for AFB1; 333 and $460 \mathrm{~nm}$ for OTA; 331 and $500 \mathrm{~nm}$ for CIT. The operating conditions are as follows: $100 \mu \mathrm{L}$ injection loop, C18 reversed phase HPLC column, ODS granulometry $5 \mu \mathrm{m}$ with identical precolumn, thermostatted at $35^{\circ} \mathrm{C}$, isocratic flow rate of $1 \mathrm{~mL} / \mathrm{min}$. The contents are calculated from a calibration curve derived from the standards.

The percentage incidence of mycotoxins was calculated using the following formula:

$\% I M=\frac{(N E C * 100)}{N E T}$

$\% \mathrm{IM}=$ Percentage of mycotoxin incidence

NEC $=$ Number of samples contaminated with mycotoxin

NET $=$ Total number of samples analyzed

\section{Extraction of the essential oil of $C$. citratus}

The essential oil was extracted using a Clevenger by hydrodistillation, a technique based on the entrainment by steam of volatile compounds contained in plant cells because of their relatively low boiling point and their hydrophobic character (Clevenger, 1928). The weighed plant material was immersed in a $15 \mathrm{~L}$ reactor containing a volume of water representing 3 times its weight. The device was assembled and brought to a boil until the essential oil contained in vegetable material was used up (approximately 5 hours). At the end of the distillation process, the essential oil was freed from traces of water by adding a pinch of sodium chloride, followed by decantation. The essential oil obtained was weighed and stored at $4^{\circ} \mathrm{C}$ in a hermetically sealed brown glass bottle. The extraction yield has been calculated according to the following formula:

Yield $(\%)=$

$\frac{\text { Mass of the extracted essential oil }}{\text { Mass of the plant material }} X 100$

\section{Chemical composition analysis by GC/MS}

The extracted $C$. citratus essential oil was analyzed by gas chromatography coupled with electron ionization mass spectrometry (GCMS-QP5000, Shimadzu) following the method described by (Tchinda, 2018). The identification of the constituents of the different essential oils was done by comparing their retention indices and mass spectra with the NIST08 database and those of the literature (Adams, 2007).

\section{In vitro antifungal activity of essential oil on toxigenic strains}

The in vitro antifungal activity on mycelial growth was evaluated by the incorporation method as described by Tchinda (2018). All the tests were done in triplicate. The mycelial growth was monitored by measuring growth diameters daily for 7 days (Tatsadjieu et al., 2009) and the percentage growth inhibition of the isolate was calculated relative to the control using the following formula (Lahlou, 2004). 


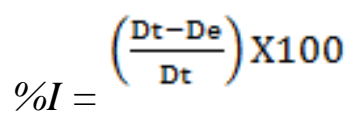

$\% \mathrm{I}=$ percentage inhibition; Dt $(\mathrm{mm})=$ Mean diameter of mycelial growth in negative control box; De $(\mathrm{mm})=$ Mean diameter of mycelial growth in test box.

To assess the susceptibility of strains to different concentrations of C. citratus, we used the method of Djeddi et al., (2007) which classifies susceptibility according to the diameter of the inhibition zone as follows:

Sensitive: $15 \mathrm{~mm} \leq \mathrm{D} \leq 19 \mathrm{~mm}$; Nonsensitive (resistant): $\mathrm{D} \leq 8 \mathrm{~mm}$.

Molds showing sensitivity to different concentrations of essential oils were selected to determine the Minimum Inhibitory Concentration (MIC). The MIC was determined using the microatmosphere method as described by Neri et al., (2006). The concentrations of $C$. citratus essential oil used for this purpose are: $0 \mu \mathrm{l} ; 2.5 \mu \mathrm{l} ; 5 \mu \mathrm{l}$; $7.5 \mu \mathrm{l} ; 10 \mu \mathrm{l}$ and $12.5 \mu \mathrm{l}$, i.e. 0 ; $30 \mathrm{ppm} ; 60$ ppm; $90 \mathrm{ppm} ; 120 \mathrm{ppm}$ and $150 \mathrm{ppm}$ respectively. After seeding and incubation, observations were made to determine the lowest concentration at which no mold growth was observed.

The minimum fungicidal concentration was assessed to confirm whether the effect is fungistatic (limiting) or fungicidal (inhibiting). It was a question of taking the strains which made it possible to determine the MIC, which one cultivated under different conditions (without essential oil) in order to appreciate the behavior of these last: if the fungus grows again, it will be said that the effect of the essential oil is fungistatic, and if the growth of the fungus stops, it will be said that the effect of the essential oil is of fungicidal nature.

\section{Statistical analysis}

IBM SPSS Statistics software (version 1.0.02482) was used for the analysis of variance (ANOVA) to determine significant differences. The Duncan test was also used to compare averages. The differences were considered significant for a $p$-value $p<0.05$.

\section{Results and discussion}

\section{Correlations of storage temperature, water content and water activity of rice seeds}

The storage temperature of the rice silos, the water content and the water activity were measured in the rice samples, and the results are presented in Table 1.No significant difference was observed at any of the sampling sites, and the storage temperature ranged from 25.27 to 26.9. However, there are similarities between samples M3, N1, N2 and T2; and also between samples Y1, Y2 and M2. According to Mutters and Thompson (2009) storage temperature generally influences fungal growth in rice seeds, and can also change the chemical composition of rice; a storage temperature of $15^{\circ} \mathrm{C}$ would be appropriate to limit losses in rice quality.

Measurements of the water content and water activity of the different rice samples (Table 1) revealed that no significant differences were observed between rice samples collected from the same site. Water content varies significantly from $10.90 \%$ to $20.77 \%$. Rice samples from the town of Maga had the lowest water content, while those from the town of Ndop had the highest values. On the other hand, it also appears from Table 1 that the rice samples collected in the cities of Yagoua and Tonga show intermediate water contents (14.24- 14.57\%) compared to those collected in the cities of Maga and Ndop. These observed differences in water content can be explained either by the degree of 
drying of rice grains before storage, or by the climatic conditions in different regions (Nguyen et al., 2007; FAO, 2002). At Maga which is located in the Far North region, the air is warm and dry unlike Ndop which is located in the North West region where the air is humid.

Table 1 also shows the water activity values in our samples. From this table it can be seen that there is no significant difference between samples from the same site, with the exception of sample Y1 from Yagoua. Minimum values were recorded for rice samples collected in Maga while samples collected in Tonga had the highest values. Statistical analysis revealed that there was no significant correlation $(\mathrm{r}=0.15 ; \mathrm{p}=0.64)$ between water content and water activity obtained in this study. (Mutters and Thompson, 2009) showed in their work that a water activity of 0.60 minimizes the activity of fungal strains, but in this work, the values obtained are between 0.65 and 0.77 , which are values that allow the development of mold. Ozbekova and Kulmyrzaev (2019) also measured water content and water activity in 15 samples of rice from 4 different geographical areas of rice cultivation (Kyrgyzstan, China, Kazakhstan, Vietnam). They found water content ranging from 10.01 to $12.92 \%$, and water activity ranging from 0.414 to 0.607 . In contrast to this study, Atungulu et al., (2016) found a strong correlation $(r=0.96)$ between water activity and water content. The low correlation obtained in this study may indicate that in the rice samples analyzed, water is more bound to the rice constituent and is therefore not fully available for fungal growth.

\section{Isolation and identification of molds}

After seeding and incubating our rice samples for 7 days, the mold contamination rates were measured and the data are recorded in Table
2. From this table it can be seen that all the samples analyzed are contaminated with mold; the contamination rates vary from 40 to $100 \%$. In general, the cities of Maga and Yagoua are the sites with the lowest mold contamination of rice. The isolation of the strains and their identification made it possible to obtain the data presented in Tables 3 and 4. From Table 3 it can be seen that the contaminating strains mainly in rice are Aspergillus, Mucor and Penicillium. The other genera such as Fusarium, Rhizopus, Alternaria and phoma have also been detected, but they are not the majority. Aspergillus, Penicillium and Fusarium have been incriminated as the main culprits for grain spoilage and these genera are present in our samples. A. versicolor has also been identified in samples from Tonga and Ndop, this strain is known to be a fungus that produces steregmatocystin, a carcinogenic toxin for the liver. Nevertheless, sterigmatocystine appears to be only 150 times less toxic than aflatoxin B1, but sterigmatocystine is a precursor to aflatoxin(Pitt and Hocking, 2009). The simultaneous presence of $A$. versicolor and $A$. fumigatus constitutes an additional risk of AFB1 contamination.

Table 4 gives us the results of the morphological and molecular identification of the different mold strains isolated from our rice samples. We counted a total of 15 fungal isolates for 8 distinct genera. Molecular identification made it possible to name all strains isolated, down to the species level, unlike the conventional method. Among the strains isolated, those likely to produce mycotoxins are the following: Aspergillus versicolor, Aspergillus fumigatus, Aspergillus carbonarius, Fusarium graminerium, Fusarium moniliform, Alternaria solani and certain species of Penicilium. However, it is important to emphasize that the presence of toxigenic strains does not automatically imply 
the presence of mycotoxins, and certain conditions must be fulfilled for them to be effectively produced (Nguyen et al., 2007). A species may be considered toxigenic, but strains or isolates do not produce mycotoxins (Noonim et al., 2008). The capacity for developing toxins is very variable for a toxigenic strain. It depends on intrinsic factors, such as "age" in Fusarium, whose toxicity decreases in culture with successive transplantations; it also depends on extrinsic factors such as $\mathrm{pH}$ and humidity, aeration conditions, temperature, microbial competition and the chemical nature of the substrate and (FAO/OMS, 2012).

\section{Mycotoxin content in rice samples}

The evaluation of the mycotoxin contamination of the different samples according to the collection site gave us the results shown in Table 5. From this table, it generally emerges that all samples analyzed contain at least one of the three mycotoxins analyzed (i.e. $100 \%$ contamination). It should also be noted that 7 of the 12 samples analyzed $(58.33 \%)$ show co-contamination and thus contain 2 or 3 mycotoxins. As regards the incidence of contamination by each of the quantified mycotoxins, it appears from Table 5 that the incidence rate of OTA, AFB1 and CIT is $50 \%(6 / 12), 58,33 \%(7 / 12)$ and $58,33 \%(7 / 12)$ respectively for the totality of rice samples analyzed with values between 0 and $1,88 \mu \mathrm{g} / \mathrm{kg}$. However, it is important to emphasize that of all the mycotoxins measured, none of them have a value exceeding the required standards. Regulation N0 1881/2006 sets at $5 \mu \mathrm{g} / \mathrm{kg}$ and $2 \mu \mathrm{g} / \mathrm{kg}$ the maximum levels of AFB1 and CIT respectively for raw cereals and derived products (or intended for direct human consumption); for OTA this value is $3 \mu \mathrm{g} / \mathrm{kg}$. These low levels can be explained by the fact that mycotoxins are reduced in white rice due to treatments such as milling and polishing
(Iqbal et al., 2016). Similar to this study, Juan et al., (2008) also reported a low incidence $(26 \%)$ and OTA content (0.08 - $0.47 \%$ $\mu \mathrm{g} / \mathrm{kg}$ ). Iqbal et al., (2016) found an incidence of $29 \%$ and $46 \%$ and a means OTA content of $8.5 \mu \mathrm{g} / \mathrm{kg}$ and $7.84 \mu \mathrm{g} / \mathrm{kg}$, respectively in white rice samples and in brown rice samples collected at Pakistan. However, very high levels of OTA between 21.3 and $26.2 \mu \mathrm{g} / \mathrm{kg}$ were reported by Trung et al., (2001) in rice samples from Vietnam. Regarding AFB1, Iqbal et al., (2016) found that 15 out of 28 $(54 \%)$ and 14 out of $34(41 \%)$ of the brown and white rice samples, respectively, were positive for AFB1. The mean levels found were $8.91 \mu \mathrm{g} / \mathrm{kg}$ and $7.70 \mu \mathrm{g} / \mathrm{kg}$ for brown and white rice, respectively. Reiter et al., (2010) found AFB1 content ranging from 0.45 to $9.86 \mu \mathrm{g} / \mathrm{kg}$ in samples of short grain rice, long grain rice, whole rice, basmati rice, as well as puffed rice from Austria.

Principal component analysis, and hierarchical clustering

Principal component analysis (PCA) and hierarchical clustering (HC) were used to observe similarities or differences between all the rice samples analyzed. On the other hand, PCA also made it possible to visualize the correlations between all the chemical parameters measured on rice seeds and the quantified mycotoxins. The principal components $\mathrm{F} 1 \mathrm{xF} 2$ explain $64.91 \%$ of the total variability in the data obtained. It can also be observed that Principal Component 1 (F1) and Principal Component 2 (F2) describe $40.61 \%$ and $24.30 \%$ of the variability in the data, respectively (Figure 3 ). The HC shows the existence of three rice groups (Figure 3 ). The characteristics of the different groups obtained are shown in Figure 2. Thus it can be seen from this figure that group I, represented by rice samples $\mathrm{T} 1, \mathrm{~N} 2, \mathrm{~T} 2, \mathrm{~T} 3, \mathrm{~N} 1$ and $\mathrm{N} 3$, is characterized by a high water activity, a high level of contamination and the mycotoxins 
present in this group are AFB1, CIT and OTA. As mentioned above, a water activity of about 0.75 promotes mold growth. Group II, represented by the $\mathrm{M} 1$ rice sample, also has a high water content and only OTA is present. Finally, Group III, represented by rice samples M2, M3, Y1, Y2 and $\mathrm{Y} 3$, is characterized by low water activity, low water content and very low fungal contamination. In this group, the mycotoxins present are OTA, AFB1 and CIT. The Group III samples are those from Yagoua and Maga, two geographically very close cities having about the same environmental characteristics, idem for Group 1 represented by the samples from Tonga and Ndop located in the Western and North-Western regions respectively.

Table.1 Water content, water activity of rice grains and storage temperature

\begin{tabular}{|l|l|l|l|l|}
\hline \multicolumn{2}{ll}{ Ricesamples } & Water content $(\%)$ & Water activity (\%) & Temperature $\left({ }^{\circ} \mathbf{C}\right)$ \\
\hline \multirow{4}{*}{ Tonga } & $\mathrm{T}_{1}$ & $14.24 \pm 0.12^{\mathrm{c}}$ & $0.75 \pm 0.03^{\mathrm{D}}$ & $26.9 \pm 1.73 \mathrm{i}$ \\
\cline { 2 - 6 } & $\mathrm{T}_{2}$ & $14.35 \pm 0.14^{\mathrm{c}}$ & $0.77 \pm 0.02^{\mathrm{D}}$ & $25.94 \pm 0.07^{\text {fghi }}$ \\
\cline { 2 - 6 } Ndop & $\mathrm{T}_{3}$ & $14.57 \pm 0.23^{\mathrm{c}}$ & $0.748 \pm 0.03^{\mathrm{D}}$ & $25.27 \pm 0.10^{\mathrm{f}}$ \\
& $\mathrm{N}_{1}$ & $20.08 \pm 0.15^{\mathrm{d}}$ & $0.66 \pm 0.03^{\mathrm{AB}}$ & $25.55 \pm 1.06^{\text {fghi }}$ \\
\cline { 2 - 6 } & $\mathrm{N}_{2}$ & $20.72 \pm 0.22^{\mathrm{e}}$ & $0.69 \pm 0.02^{\mathrm{AB}}$ & $25.64 \pm 0.34^{\text {tghi }}$ \\
\cline { 2 - 6 } & $\mathrm{N}_{3}$ & $20.77 \pm 0.42^{\mathrm{e}}$ & $0.66 \pm 0.03^{\mathrm{AB}}$ & $25.43 \pm 0.54^{\mathrm{hi}}$ \\
\hline \multirow{3}{*}{ Yagoua } & $\mathrm{Y}_{1}$ & $14.48 \pm 0.35^{\mathrm{c}}$ & $0.70 \pm 0.01^{\mathrm{C}}$ & $26.13 \pm 0.16^{\text {fgh }}$ \\
\cline { 2 - 5 } & $\mathrm{Y}_{2}$ & $14.20 \pm 0.25^{\mathrm{c}}$ & $0.68 \pm 0.01^{\mathrm{AB}}$ & $26.33 \pm 0.26^{\text {fgh }}$ \\
\cline { 2 - 5 } & $\mathrm{Y}_{3}$ & $14.49 \pm 0.30^{\mathrm{c}}$ & $0.68 \pm 1.40^{\mathrm{AB}}$ & $26.46 \pm 0.10^{\text {fg }}$ \\
\hline & $\mathrm{M}_{1}$ & $10.90 \pm 0.30^{\mathrm{ab}}$ & $0.67 \pm 0.01^{\mathrm{AB}}$ & $26.52 \pm 0.15^{\mathrm{hi}}$ \\
\cline { 2 - 5 } & $\mathrm{M}_{2}$ & $10.49 \pm 0.27^{\mathrm{a}}$ & $0.65 \pm 0.01^{\mathrm{AB}}$ & $25.66 \pm 0.25^{\text {fgh }}$ \\
\cline { 2 - 5 } & $\mathrm{M}_{3}$ & $11.36 \pm 0.46^{\mathrm{b}}$ & $0.66 \pm 0.01^{\mathrm{AB}}$ & $26.07 \pm 0.25^{\text {fghi }}$ \\
\hline
\end{tabular}

Table2. Mould contamination rate of rice

\begin{tabular}{|l|l|c|}
\hline \multicolumn{2}{|l|}{ Rice samples } & Mould contamination rate (\%) \\
\hline \multirow{5}{*}{ Tonga } & $\mathrm{T}_{1}$ & 100 \\
\cline { 2 - 3 } & $\mathrm{T}_{2}$ & 90 \\
\cline { 2 - 3 } Ndop & $\mathrm{T}_{3}$ & 90 \\
\hline \multirow{5}{*}{ Yagoua } & $\mathrm{N}_{1}$ & 90 \\
\cline { 2 - 3 } & $\mathrm{N}_{2}$ & 100 \\
\cline { 2 - 3 } & $\mathrm{N}_{3}$ & 100 \\
\hline \multirow{5}{*}{ Maga } & $\mathrm{Y}_{1}$ & 70 \\
\cline { 2 - 3 } & $\mathrm{Y}_{2}$ & 60 \\
\cline { 2 - 3 } & $\mathrm{Y}_{3}$ & 40 \\
\hline & $\mathrm{M}_{1}$ & 60 \\
\cline { 2 - 3 } & $\mathrm{M}_{2}$ & 40 \\
\cline { 2 - 3 } & $\mathrm{M}_{3}$ & 40 \\
\hline
\end{tabular}


Table.3 Frequency of occurrence of strains depending on the sampling site

\begin{tabular}{|c|c|c|}
\hline $\begin{array}{l}\text { Sample } \\
\text { Collection } \\
\text { Locations }\end{array}$ & Isolated strains & Frequency of strain occurrence $(\%)$ \\
\hline \multirow[t]{6}{*}{ Tonga } & Aspergillus versicolor & 40 \\
\hline & Penicilium citrinum & 20 \\
\hline & Mucor sp. & 20 \\
\hline & Fusarium graminerium & 10 \\
\hline & Alternaria sp & 10 \\
\hline & Fusarium moniliforme & 20 \\
\hline \multirow[t]{5}{*}{ Ndop } & Aspergillus fumigatus & 30 \\
\hline & Aspergillus versicolor & 30 \\
\hline & Rhyzopus sp. & 30 \\
\hline & Mucor sp. & 10 \\
\hline & $n i$ & 10 \\
\hline \multirow[t]{5}{*}{ Yagoua } & Penicilium sp. & 40 \\
\hline & Mucor sp. & 30 \\
\hline & Rhyzopus sp. & 20 \\
\hline & phoma sp. & 10 \\
\hline & $n i$ & 10 \\
\hline \multirow[t]{4}{*}{ Maga } & Aspergillus carbonarius & 40 \\
\hline & Fusarium sp. & 30 \\
\hline & Mucor sp. & 20 \\
\hline & Penicilium sp. & 20 \\
\hline
\end{tabular}

Table.4 Comparison of dominant molds species identified in rice by classical culturing techniques and by PCR-sequencing

\begin{tabular}{|c|c|c|c|c|}
\hline \multirow{2}{*}{$\begin{array}{l}\text { Strain } \\
\text { numbers }\end{array}$} & \multirow{2}{*}{$\begin{array}{l}\text { Morphological } \\
\text { identification }\end{array}$} & \multicolumn{3}{|l|}{ Molecular identification } \\
\hline & & Strain name & $\begin{array}{l}\text { Identification } \\
\text { frequency }(\%)\end{array}$ & $\begin{array}{l}\text { Query cover } \\
(\%)\end{array}$ \\
\hline 1 & Alternaria sp. & Alternaria solani & 100 & 100 \\
\hline 2 & Aspergillus carbonarius & Aspergillus carbonarius & 100 & 100 \\
\hline 3 & Aspergillus fumigatus & Aspergillus fumigatus & 100 & 100 \\
\hline 4 & Aspergillus versicolor & Aspergillu sversicolor & 100 & 100 \\
\hline 5 & Fusarium sp. & Fusarium oxyparum & 99 & 100 \\
\hline 6 & Fusarium graminearum & Fusarium graminearuum & 100 & 100 \\
\hline 7 & Fusarium moniliforme & Fusarium moniliforme & 100 & 100 \\
\hline 8 & Mucor sp. & Mucor hiemalis & 99 & 100 \\
\hline 9 & Rhyzopus sp & Rhyzopus oryzae & 99 & 100 \\
\hline 10 & Penicilium sp. & Penicilium expansum & 96 & 100 \\
\hline 11 & Penicilium citrinum & Penicilium citrinum & 99 & 100 \\
\hline 12 & Rhyzopu ssp. & Rhizopus nigricans & 100 & 100 \\
\hline 13 & Phoma sp & Phoma glomerata & 98 & 100 \\
\hline 14 & $n i$ & Acremonium murorum & 91 & 99 \\
\hline 15 & $n i$ & Wallemia muriae & 95 & 99 \\
\hline
\end{tabular}


Table.5 Mycotoxin content $(\mu \mathrm{g} / \mathrm{kg}$ ) quantified in rice grains

\begin{tabular}{|c|c|c|c|c|}
\hline \multicolumn{2}{|c|}{ Ricesamples } & OTA content $(\mu \mathrm{g} / \mathrm{kg})$ & CIT content $(\mu \mathrm{g} / \mathrm{kg})$ & AFB 1 content $(\mu \mathrm{g} / \mathrm{kg})$ \\
\hline \multirow[t]{3}{*}{ Tonga } & $T_{1}$ & $0 \pm 0^{j}$ & $0.31 \pm 0.02^{J}$ & $1.38 \pm 0.13^{\mathrm{t}}$ \\
\hline & $T_{2}$ & $0.87 \pm 0.03^{\mathrm{n}}$ & $0.16 \pm 0.01^{\mathrm{K}}$ & $0.69 \pm 0.02^{\mathrm{s}}$ \\
\hline & $T_{3}$ & $0 \pm 0^{j}$ & $0.24 \pm 0.03^{\mathrm{L}}$ & $0 \pm 0^{\mathrm{q}}$ \\
\hline \multirow[t]{3}{*}{ Ndop } & $\mathrm{N}_{1}$ & $0 \pm 0^{j}$ & $0.93 \pm 0.02^{P}$ & $0.13 \pm 0.02^{\mathrm{q}}$ \\
\hline & $\mathrm{N}_{2}$ & $0.23 \pm 0.04^{1}$ & $0 \pm 0^{J}$ & $0 \pm 0^{\mathrm{q}}$ \\
\hline & $\mathrm{N}_{3}$ & $0.35 \pm 0.02^{\mathrm{m}}$ & $0.30 \pm 0.02^{\mathrm{M}}$ & $0 \pm 0^{q}$ \\
\hline \multirow[t]{3}{*}{ Yagoua } & $\mathrm{Y}_{1}$ & $0 \pm 0^{j}$ & $0.16 \pm 0.02^{\mathrm{K}}$ & $0.34 \pm 0.03^{r}$ \\
\hline & $\mathrm{Y}_{2}$ & $0.13 \pm 0.03^{\mathrm{k}}$ & $0.21 \pm 0.03^{\mathrm{L}}$ & $1.57 \pm 0.23^{\mathrm{v}}$ \\
\hline & $Y_{3}$ & $0 \pm 0^{j}$ & $0 \pm 0^{\mathrm{J}}$ & $0.46 \pm 0.05^{\mathrm{r}}$ \\
\hline \multirow[t]{3}{*}{ Maga } & $\mathrm{M}_{1}$ & $1.88 \pm 0.03^{\circ}$ & $0 \pm 0^{J}$ & $0 \pm 0^{\mathrm{q}}$ \\
\hline & $\mathrm{M}_{2}$ & $0.34 \pm 0.03^{\mathrm{m}}$ & $0.64 \pm 0.05^{\mathrm{N}}$ & $0.11 \pm 0.02^{q}$ \\
\hline & $\mathrm{M}_{3}$ & $0 \pm 0^{\mathrm{j}}$ & $0.81 \pm 0.03^{\mathrm{O}}$ & $0 \pm 0^{\mathrm{q}}$ \\
\hline
\end{tabular}

$0=$ not determined

Table.6 Chemical composition of C. citratus

\begin{tabular}{|c|c|c|}
\hline Retention Index & Compounds & C.citratus \\
\hline & Monoterpenes & 98.5 \\
\hline & $\begin{array}{l}\text { Monoterpenes } \\
\text { hydrocarbons }\end{array}$ & 11.7 \\
\hline 992 & myrcene & 10.8 \\
\hline 1037 & (Z)- $\beta$-Ocimene & 0.6 \\
\hline \multirow[t]{2}{*}{1047} & (E)- $\beta$-Ocimene & 0.3 \\
\hline & $\begin{array}{l}\text { Monoterpenes } \\
\text { oxygenated }\end{array}$ & 86.8 \\
\hline 1102 & Linalol & 0.8 \\
\hline 1146 & Isocitral « exo » & 0.2 \\
\hline 1154 & Citronellal & 0.3 \\
\hline 1166 & Thujanol « $3 »$ & 1.0 \\
\hline 1184 & Isocitral « $\mathrm{Z} »$ & 1.6 \\
\hline 1231 & Nerol & 0.6 \\
\hline 1246 & Neral & 33.5 \\
\hline 1257 & Geraniol & 5.2 \\
\hline 1276 & Geranial & 42.4 \\
\hline \multirow{2}{*}{1386} & Geranyl acetate & 1.2 \\
\hline & $\begin{array}{l}\text { Aliphatic } \\
\text { compounds }\end{array}$ & 2.2 \\
\hline 987 & 6-methylhept-5-èn-2-one & 1.7 \\
\hline 1685 & Benylate & 0.5 \\
\hline Total & I & 100 \\
\hline
\end{tabular}


Table.7 Inhibition (\%) of the mycelial growth of A. carbonarius, A. versicolor, F. moniliform, $F$. graminaerum and $P$. citrinum by the essential oil of $C$. citratus during MIC research

\begin{tabular}{|c|c|c|c|c|c|}
\hline \multirow[t]{2}{*}{ Concentration } & A. carbonarius & A. versicolor & F. moniliform & F. graminaerum & P. citrinum \\
\hline & \multicolumn{5}{|c|}{ Inhibition (\%) } \\
\hline 400 & $100 \pm 0$ & $100 \pm 0$ & $100 \pm 0$ & $100 \pm 0$ & $100 \pm 0$ \\
\hline 375 & $100 \pm 0$ & $100 \pm 0$ & $96.41 \pm 1.02$ & $100 \pm 0$ & $100 \pm 0$ \\
\hline 350 & $100 \pm 0$ & $100 \pm 0$ & $91.05 \pm 0.45$ & $100 \pm 0$ & $100 \pm 0$ \\
\hline 300 & $100 \pm 0$ & $100 \pm 0$ & $77.31 \pm 2.56$ & $100 \pm 0$ & $100 \pm 0$ \\
\hline 275 & $100 \pm 0$ & $91.36 \pm 2.88$ & $36.46 \pm 1.35$ & $80.77 \pm 2.39$ & $85.32 \pm 2.80$ \\
\hline 250 & $84.38 \pm 1.55$ & $61.98 \pm 1.84$ & I & $41.38 \pm 1.21$ & $58.86 \pm 3.75$ \\
\hline 200 & $62.02 \pm 1.53$ & $37.48 \pm 0.82$ & l & l & $27.76 \pm 0.99$ \\
\hline
\end{tabular}

Fig.1 Distribution of rice grain samples and measured parameters on the PCA F1*F2 axis plane

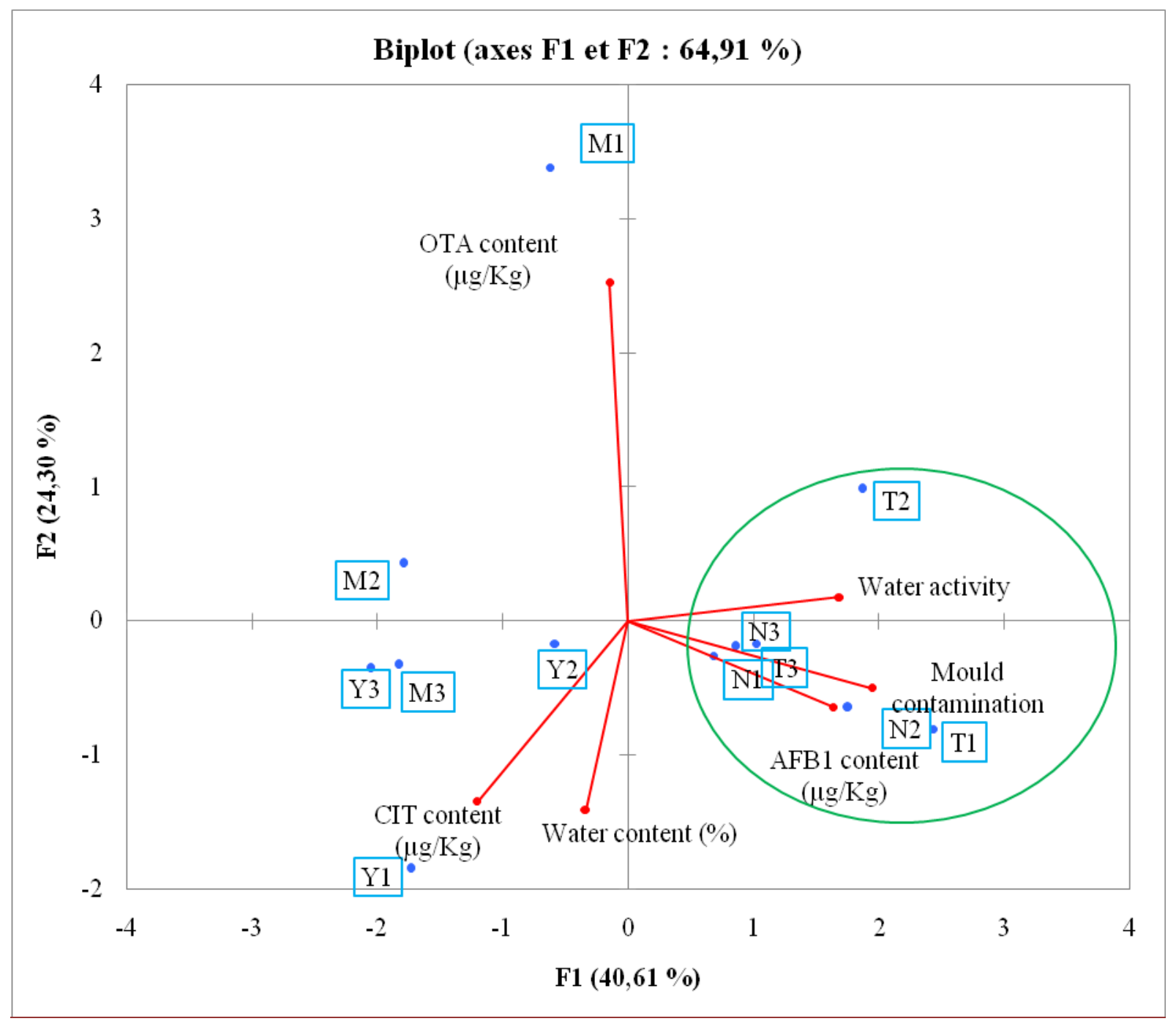


Fig.2 Classification of different groups of rice grain samples

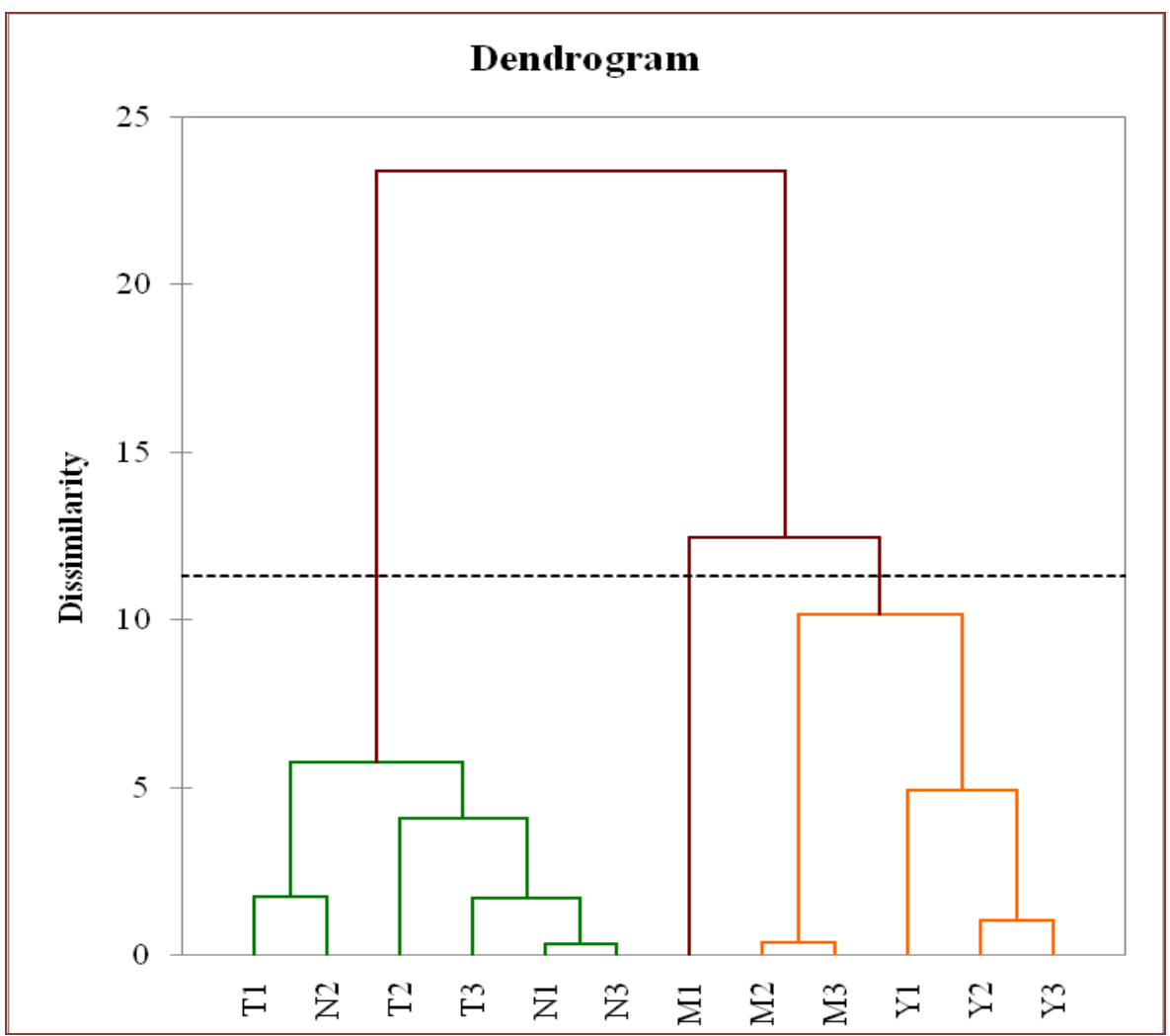

Fig.3 Profile of the different groups of rice grain samples (1: group 1; 2: group 2; 3: group 3)

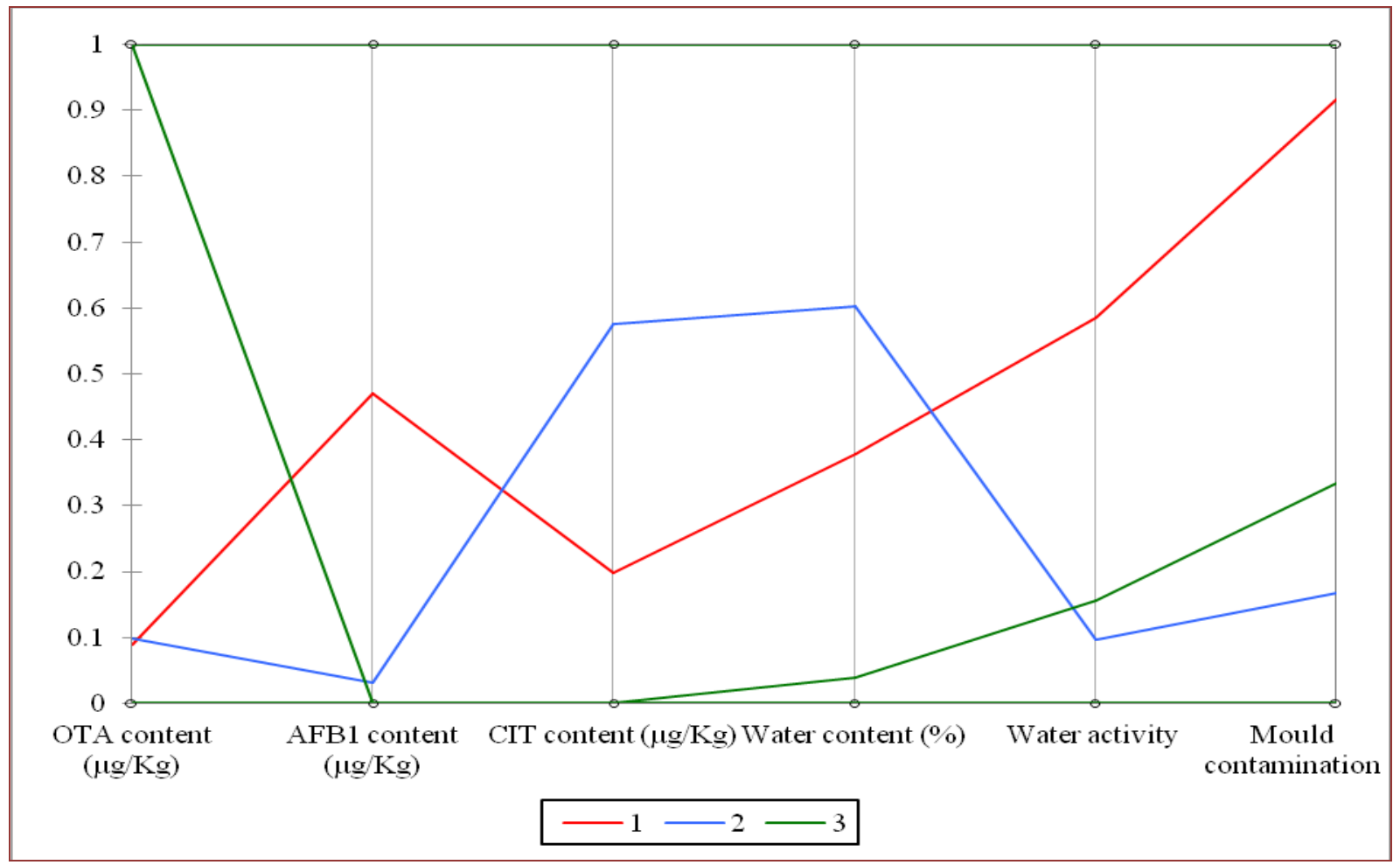




\section{Yield and composition of the essential oil}

After extraction of $15 \mathrm{~kg}$ of fresh leaves of Cymbopogon citratus by hydrodistillation, $103 \mathrm{~mL}$ of essential oil was obtained, resulting in a yield of $0.68 \%$. This yield is similar to those obtained by Tchoumbougnang et al., (2009) (0.67\%) and Akono Ntonga et al., (2014) $(0.6 \%)$ by distillation respectively of dry and fresh leaves of $C$. citratus in Douala (Cameroon). However, it is higher than that of Tchinda (2018), which had a yield of $0.4 \%$. The differences observed between these results may be due to parameters such as pretreatment of the plant material before distillation (drying, grinding), hydrodistillation time, storage time of the plant material after harvest, place of harvest, vegetative stage of the plant, collection period and climate (Barbelet, 2015). The chemical composition of the essential oil extracted and analyzed by GC/MS provided the results reported in Table 6. Chemical analysis of EO from $C$. citratus reveals that it contains 15 compounds. Of these compounds, the monoterpenes $(98.5 \%)$ are noted as major compounds, with a preponderance of oxygenated compounds (86.8\%). The majority compounds in this essential oil are geranial (42.4\%), neral (33.5\%) and myrcene (10.8). There is a total absence of sesquiterpenes in this essential oil. These results corroborate those of several authors, Tzortzakis and Economakis (2007) who obtained in Greece $40.8 \%$ geranial and 31.9\% neral, Tchoumbougnang et al., (2009) who obtained geranial (39.3\%) and neral (21.9\%) for a sample collected in Douala (Cameroon), and Tchinda (2018)who obtained geranial $(42.7 \%)$ and neral $(33.0 \%)$ for a sample collected in Douala (Cameroon). In spite of the variations observed in the proportions, generally the essential oil of $C$. citratus is rich in citrals (Geranial and Neral) which are considered to be the markers of Lemongrass.

\section{Antifungal activity of the essential oil of $C$. citratus}

Table 7 summarizes the different MICs obtained with the $C$. citratus essential oil tested. Generally, we can see in this table that the percentage of inhibition increases with the concentration of essential oil, whatever the nature of the oil or pathogen, until reaching the percentage of $100 \%$ inhibition relative to the concentration corresponding to the MIC. The Minimum Inhibitory Concentration (MIC) is therefore defined as the lowest concentration at which an essential oil completely inhibits the visible growth of a given germ. Thus, it varies according to the germ. MIC analysis shows that the essential oil of $C$. citratus is very active. Among the five strains tested, A. carbonarius is the most sensitive strain, as it has the lowest MIC values, and $F$. moniliform is the most resistant strain with the highest MIC value. Nguefack et al., (2007) showed that $C$. citratus essential oil inhibits the growth of Alternariapad wickii and Bipolaris oryzae at MICs of 900 and 800 ppm respectively. In addition, Tchinda (2018) showed that EO of $C$. citratus inhibited the growth of F. moniliform with a MIC of 500 ppm after 7 days incubation on strains isolated from dessert bananas.

Conclusion of the study is as follows:

At the end of this work, which was aimed to establish the fungal profile, to determine the OTA, AFB1 and CIT contents and to evaluate the efficacy of $C$. citratus essential oil on the toxigenic strains of rice produced in different regions of Cameroon, we can conclude that the three mycotoxins tested are indeed present in our rice samples, but at values not exceeding those specified in Regulation N0 $1881 / 2006$. On the other hand, 9 fungal genera have been identified and the dominant genera are Aspergillus, Penicillium and Fusarium, which are all involved in the 
synthesis and excretion of mycotoxins in cereals. The essential oil of $C$. citratus has been shown to be effective in inhibiting the growth of $A$. carbonarius, A. versicolor, $F$. graminaerum, $F$. moniliform and $P$. citrinum; and the predominant compounds of this oil are geranial (42.4\%), neral (33.5\%) and myrcene (10.8). This essential oil can be used as a bio-fungicide for the post-harvest treatment of rice. However, although having shown its effectiveness on these strains, this alternative proves to be difficult to implement because the hydrophobic nature of essential oils, their sensitivity to external factors and their volatility make them difficult to use and this difficulty could be circumvented by appropriate formulation.

\section{Acknowledgements}

This work was supported by the Biotechnology Laboratory of the University Institute of Technology of the University of Ngaoundéré, which spared no effort in carrying out this work.

\section{References}

Adams, R.P., 2007. Identification of Essential Oil Components By Gas Chromatography/Mass Spectrometry, 4th ed. Allured Pub Corp, Carol Stream, Ill.

Akono Ntonga, P., Baldovini, N., Mouray, E., Mambu, L., Belong, P., Grellier, P., 2014. Activity of Ocimum basilicum, Ocimum canum, and Cymbopogon citratus essential oils against Plasmodium falciparum and maturestage larvae of Anopheles funestus s.s. Parasite 21, 1-8. https://doi.org/10.1051/parasite/201403 3

Alshannaq, A., Yu, J.-H., 2017. Occurrence, toxicity, and analysis of major mycotoxins in food. Int. J. Environ.
Res. Public. Health 14, 632. https://doi.org/10.3390/ijerph14060632

Amadioha, A.C., 2000. Controlling rice blast in vitro and in vivo with extracts of Azadirachta indica. Crop Prot. 19, 287290. https://doi.org/10.1016/S02612194(99)00080-0

Atungulu, G.G., Thote, S., Wilson, S., 2016. Storage of hybrid rough rice Consideration of microbial growth kinetics and prediction models. J. Stored Prod. Res. 69, 235-244. https://doi.org/10.1016/j.jspr.2016.09.00 3

Barbelet, S., 2015. Le giroflier: historique, description et utilisations de la plante et de son huile essentielle (other). Université de Lorraine.

Bavaro, S.L., Susca, A., Frisvad, J.C., Tufariello, M., Chytiri, A., Perrone, G., Mita, G., Logrieco, A.F., Bleve, G., 2017. isolation, characterization, and selection of molds associated to fermented black table olives. Front. Microbiol. 8, 1-14. https://doi.org/10.3389/fmicb.2017.013 56

Bengyella, L., Nguefack, J., Pranab, R., 2011. Evaluation of antifungal potential of Ocimum gratissimum extracts on two seedborne fungi of rice (Oryza sativa L.) in Cameroon. Asian J. Biol. Sci. 4, 306-311.

Bennett, J.W., Klich, M., 2003. Mycotoxins. Clin. Microbiol. Rev. 16, 497-516. https://doi.org/10.1128/CMR.16.3.497516.2003

Booth, C., 1977. Fusarium: laboratory guide to the identification of the major species. Commonwealth Mycological Institute, Université de Cornell.

Clevenger, J.F., 1928. Apparatus for the determination of volatile oil. J. Am. Pharm. Assoc. 17, 345-349. https://doi.org/10.1002/jps.3080170407

Djeddi, S., Bouchenah, N., Settar, I., Skaltsa, 
H.D., 2007. Composition and antimicrobial activity of the essential oil of Rosmarinus officinalis from Algeria. Chem. Nat. Compd. 43, 487-490. https://doi.org/10.1007/s10600-0070172-4

El Sheikha, A.F., Nganou, N.D., 2018. Molecular Characterization of Ochratoxigenic Fungal Flora as an Innovative Tool to Certify Coffee Origin, in: El Sheikha, A.F., Levin, R., $\mathrm{Xu}$, J. (Eds.), Molecular Techniques in Food Biology. John Wiley \& Sons, Ltd, Chichester, UK, pp. 47-69. https://doi.org/10.1002/9781119374633. ch3

FAO, 2011. Rural structures in the tropics: design and development. FAO, Rome, Italy.

FAO, 2002. Proceedings of the 20th session of the international rice commission. Sustainable rice production for food security. Bangkok, Thailand.

FAO/OMS, 2012. Prévention et réduction de la contamination des produits de consommation humaine et animale, 2nd Edition. ed, codex alimentarius. RomeItalie.

Folefack, D.P., Abou, S., 2016. Contribution à l'économie locale des microentreprises de transformation des céréales dans la ville de Maroua, Cameroun. Tropicultura 34, 186-192.

Iftikhar, T., Niaz, M., Hussain, Y., Abbas, S.Q., Ashraf, I., Zia, M.A., 2010. Improvement of selected strains through gamma irradiation for enhanced lipolytic potential. Pak. J. Bot. 42, 2257-2267.

Iqbal, S.Z., Asi, M.R., Hanif, U., Zuber, M., Jinap, S., 2016. The presence of aflatoxins and ochratoxin $\mathrm{A}$ in rice and rice products; and evaluation of dietary intake. Food Chem. 210, 135-140. https://doi.org/10.1016/j.foodchem.2016 .04 .104
Kossou, D.K., Aho, N., 1993. Stockage et conservation des grains alimentaires tropicaux: principes et pratiques. Les Éditions du Flamboyant, Cotonou, Benin.

Lahlou, M., 2004. Methods to study the phytochemistry and bioactivity of essential oils. Phytother. Res. 18, 435448. https://doi.org/10.1002/ptr.1465

Laib, I., 2011. Etude des activités antioxydante et antifongique de l'huile essentielle des fleurs sèches de Lavandula officinalis sur les moisissures des légumes secs (Magister en Sciences Alimentaires). Université Constantine 1 (ex Mentouri), Algérie.

Moreau, C., 1974. Moisissures toxiques dans l'alimentation, 2. éd. revue et augm edition. ed. Masson, Paris.

Mutters, R.G., Thompson, J.F., 2009. Rice Quality Handbook, Agriculture and Natural Resources. ed. UCANR Publications, University of California.

Neri, F., Mari, M., Brigati, S., 2006. Control of Penicillium expansum by plant volatile compounds. Plant Pathol. 55, 100-105.

https://doi.org/10.1111/j.13653059.2005.01312.x

Nganou, N.D., Durand, N., Tatsadjieu, N.L., Métayer, I., Montet, D., Mbofung, C.M.F., 2014. Fungal flora and ochratoxin A associated with coffee in Cameroon. Br. Microbiol. Res. J. 4, 117.

https://doi.org/10.9734/BMRJ/2014/428 4

Ngono, A.N., Biyiti, L., Zollo, P.H., Bouchet, P., 2000. Evaluation of antifungal activity of extracts of two Cameroonian rutaceae: Zanthoxylum leprieurii Guill. et Perr. and Zanthoxylum xanthoxyloides Waterm. J. Ethnopharmacol. 70, 335-342. https://doi.org/10.1016/s03788741(99)00188-9 
Nguefack, J., Nguikwie, S.K., Fotio, D., Dongmo, B., Zollo, P.H.A., Leth, V., Nkengfack, A.E., Poll, L., 2007. Fungicidal potential of essential oils and fractions from Cymbopogon citratus, Ocimum gratissimum and Thymus vulgaris to control Alternaria padwickii and Bipolaris oryzae, two seed-borne fungi of rice (Oryza sativa L.). J. Essent. Oil Res. JEOR 19, 581-587. https://doi.org/10.1080/10412905.2007. 9699336

Nguyen, M., Tozlovanu, M., Tran, T., Pfohlleszkowicz, A., 2007. Occurrence of aflatoxin B1, citrinin and ochratoxin $\mathrm{A}$ in rice in five provinces of the central region of Vietnam. Food Chem. 105, 42-47.

https://doi.org/10.1016/j.foodchem.2007 .03 .040

Noonim, P., Mahakarnchanakul, W., Nielsen, K.F.J., Frisvad, C., Samson, R.A., 2008. Isolation, identification and toxigenic potential of ochratoxin A -producing Aspergillus species from coffee beans grown in two regions of Thailand. Int. J. Food Microbiol. 128, 197-202.

Ozbekova, Z., Kulmyrzaev, A., 2019. Study of moisture content and water activity of rice using fluorescence spectroscopy and multivariate analysis. Spectrochim. Acta. A. Mol. Biomol. Spectrosc. 223, $1-7$.

https://doi.org/10.1016/j.saa.2019.1173 57

Park, J.W., Kim, E.K., Shon, D.H., Kim, Y.B., 2002. Natural co-occurrence of aflatoxin B1, fumonisin B1 and ochratoxin A in barley and corn foods from Korea. Food Addit. Contam. 19, 1073-1080.

https://doi.org/10.1080/0265203021015 1840

Pitt, J.I., Hocking, A.D., 2009. Fungi and Food Spoilage. Springer US, Boston, MA. https://doi.org/10.1007/978-0-387-
92207-2

Regnault-Roger, C., Philogene, B.J.R., Vincent, C., 2008. Biopesticides d'origine végétale, (2e éd.). ed. Lavoisier, France.

Reiter, E.V., Vouk, F., Böhm, J., RazzaziFazeli, E., 2010. Aflatoxins in rice - A limited survey of products marketed in Austria. Food Control 21, 988-991. https://doi.org/10.1016/j.foodcont.2009. 12.014

Samson, R.A., Hoekstra, E.S., Frisvad, J.C., 2004. Introduction to Food- and Airborne Fungi, Utrecht : Centraalbureau voor Schimmel cultures. ed. Netherlands.

Siewe, F.B., Mbougueng, P.D., Tatsadjieu, L.N., Noumo, T.N., Mbofung, C.M.F., 2015. The Potential Application of Syzygium aromaticum, and Cymbopogon citratus Essential Oils as Natural Preservatives of Beef Patties. Food Nutr. Sci. 06, 374-385. https://doi.org/10.4236/fns.2015.63038

Tatsadjieu, N.L., Dongmo, P.M.J., Ngassoum, M.B., Etoa, F.-X., Mbofung, C.M.F., 2009. Investigations on the essential oil of Lippia rugosa from Cameroon for its potential use as antifungal agent against Aspergillus flavus Link ex. Fries. Food Control 20, 161-166. https://doi.org/10.1016/j.foodcont.2008. 03.008

Tchinda, S.E., 2018. Formulation d'un biofongicide à base d'huiles essentielles pour le contrôle des pertes post-récoltes de la banane dessert (Musa acuminata Colla) (These de Doctorat Ph.D). Ecole Nationale Superieure des Sciences Agro-Industrielles /Universite de Ngaoundéré, Ngaoundéré-Cameroun.

Tchoumbougnang, F., Dongmo, P.M.J., Sameza, M.L., Mbanjo, E.G.N., Fotso, G.B.T., Zollo, P.H.A., Menut, C., 2009. Activité larvicide sur Anopheles gambiae Giles et composition chimique 
des huiles essentielles extraites de quatre plantes cultivées au Cameroun. Biotechnol. Agron. Soc. Environ. 13, 77-84.

Trung, T.S., Bailly, J.D., Querin, A., 2001. Fungal contamination of rice from south Vietnam, mycotoxinogenesis of selected strains and residues in rice. Rev. Médecin Véterinaire 152, 555-560.

Tzortzakis, N.G., Economakis, C.D., 2007. Antifungal activity of lemongrass (Cympopogon citratus L.) essential oil against key postharvest pathogens. Innov. Food Sci. Emerg. Technol. 8,
253-258.

https://doi.org/10.1016/j.ifset.2007.01.0 02

Wopereis, S., Rubingh, C.M., van Erk, M.J., Verheij, E.R., van Vliet, T., Cnubben, N.H.P., Smilde, A.K., van der Greef, J., van Ommen, B., Hendriks, H.F.J., 2009. Metabolic Profiling of the Response to an Oral Glucose Tolerance Test Detects Subtle Metabolic Changes. PLoS ONE 4, 1-13.

https://doi.org/10.1371/journal.pone.000 4525.

\section{How to cite this article:}

Nganou, N. D., E. S. Tchinda, A. T. Sokamte, M.T.N. Beumo, S. F. Nodem and Tatsadjieu, L. N. 2020. Antifungal Activity of Cymbopogon citratus Essential Oil on Toxigenic Fungal Strains Isolated from Cameroonian Rice. Int.J.Curr.Microbiol.App.Sci. 9(08): 79-96. doi: https://doi.org/10.20546/ijcmas.2020.908.009 